\title{
ROLE OF GEMINI SURFACTANTS IN FIGHT AGAINST COVID19
}

\author{
Rajpreet Kaur 1, Dr. Anita Gupta ${ }^{*}$ 四 \\ ${ }^{1}$ Research Scholar, Amity Institute of Applied Sciences, Amity University, AUUP, Noida, India \\ ${ }^{* 2}$ Associate Professor, Amity Institute of Applied Sciences, Amity University, Noida, India
}

DOI: https://doi.org/10.29121/ijetmr.v7.i12.2020.807

Article Citation: Rajpreet Kaur, and Dr. Anita Gupta. (2020). ROLE OF GEMINI SURFACTANTS IN FIGHT AGAINST COVID19. International Journal of Engineering Technologies and Management Research, 7(12), 1-16. https://doi.org/10.29121/ijetmr.v7 .i12.2020.807

Published Date: 09 December 2020

Keywords:

COVID-19

Hand Washing

Ozone

Quaternary Ammonium Compounds And Gemini Surfactants Micelles

\begin{abstract}
COVID-19, a pandemic, threatens the entire world by its multiplicative deadly behavior. Virus has caged the world's people into their homes / isolation as their protective gear. Transmission rate, Case Fatality Rate, and Asymptomatic Transmission parameters determine the savage of COVID19. More than a couple of months, mankind is staying locked in one's home, which has never happened in the lifetime of any other generation. World Health Organization highlights the importance of hand Hygiene (Handwashing) by Soap/surfactant for 20 seconds and the use of alcoholbased Sanitizers as a part of personal health care. Soap functions as a weapon for sterilization of any viruses present on the surface. The lipid envelope of virusesis more susceptible to heat, desiccation or action of surfactants. Single tailed Quaternary ammonium compound surfactant is most commonly used as disinfectant or cleaning agent. Similarly, Gemini surfactants can also play a vital role as disinfectant / sanitizerin future. It is suggested that Gemini surfactants have imperative function in Air sanitation. Also, there is a valid comparison of Coronavirus with other SARS diseases. The deadly nature of virus can be understood by knowing its mechanism of action and mode of transmission. Once a chain of human to human transmission is initiated then it is very tricky to rupture the chain.
\end{abstract}

\section{INTRODUCTION}

\subsection{COVID: A NOXIOUS PARTICLE IN THE VICINITY}

The new type of Coronavirus, 2019-nCOV was detected by an outbreak in Wuhan city, Hubei province, China. The estimated incubation period of this virus is 14 days was announced by U.S. Centres for Disease Control and Prevention on 31stJan. 2020 [1], [2]. Among the globally reported COVID-19 cases, $16 \%$ have been severe, only $2.2 \%$ fatal. Human-to-human transmission was found in health care settings and general family clusters, in various countries. There is a possible threat of exponential growth of the number of cases worldwide as evident from the Reception binding analysis of this novel virus to human cells.

No virus can exhaust the untiring spirit of Mankind. WHO has launched Strategic preparedness and Response Plan which includes tracking the spread of the virus, better equipment for health workers, readily available testing kits, providing water, sanitation, and hygiene to the vulnerable families and children to protect them from COVID19.

(C) 2020 The Author(s). This is an open access article distributed under the terms of the Creative Commons Attribution License, which permits unrestricted use, distribution, and reproduction in any medium, provided the original author and source are credited. 
Globally, the Total number of COVID-19 Active cases 7,904,702, Death from COVID-19-1,033,330 and Recovered cases from COVID-19-25,897,996 have been reported in Oct.3, 2020 (Figure 1a). The updated overall numbers of total cases in Region Wise including Total Active cases, Total death, and Total Recovery cases have shown in Bar graph (Figure 1b).

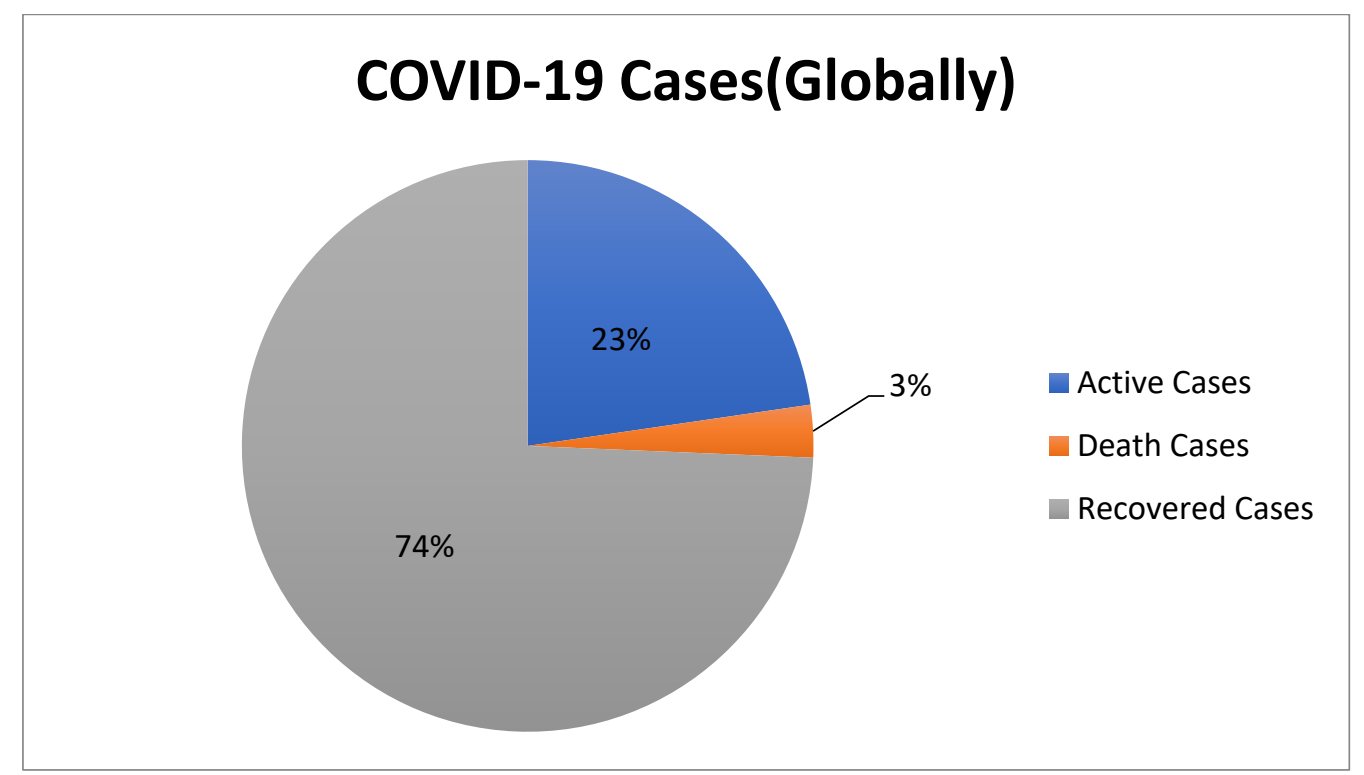

Figure 1a: Represents the percentage analysis of COVID- 19 cases Worldwide.

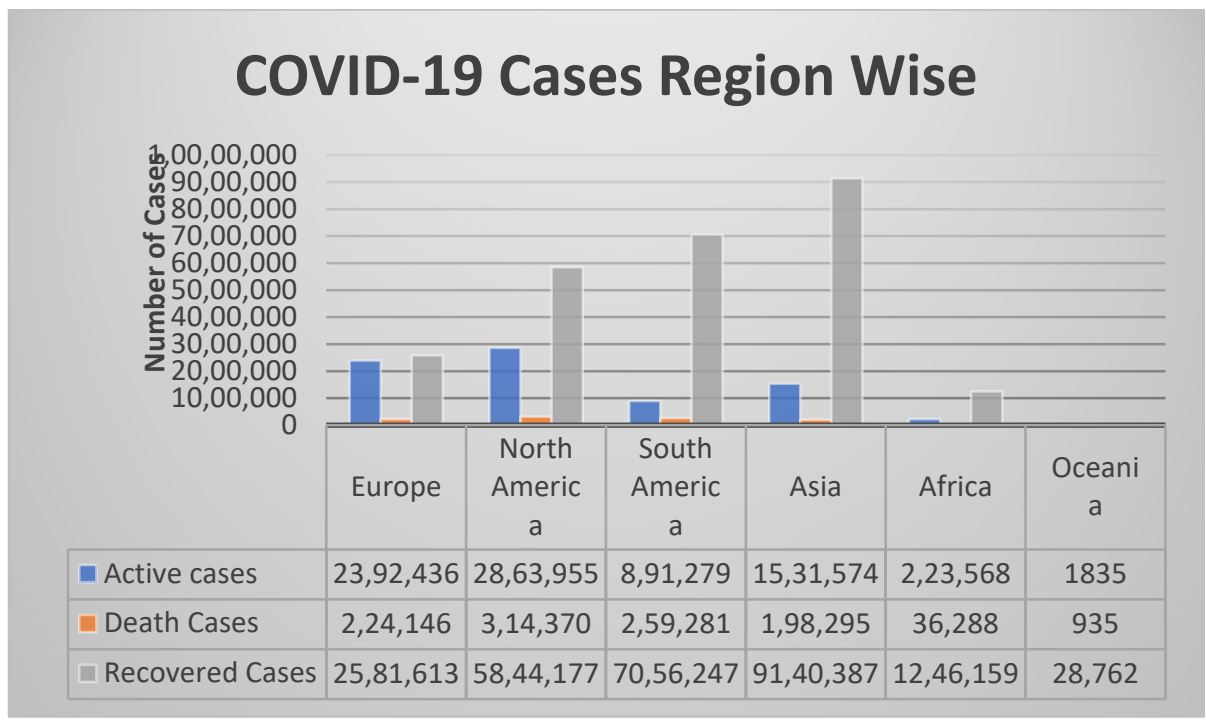

Figure 1b: Represents the Number of Cases of COVID- 19 Region Wise.

Terminology of virus: The word Corona originates from protrusion of spikes like a crown on the surface of the virus. A virus can be classified into three categories: Alpha category- 229E (alpha coronavirus), NL63 (alpha coronavirus), Beta category- OC43 (beta coronavirus), HKU1 (beta coronavirus), MERS-CoV (the beta coronavirus that causes Middle East Respiratory Syndrome, or MERS), SARS-CoV (the beta coronavirus that causes severe acute respiratory syndrome, or SARS), SARS-CoV-2 (the novel coronavirus that causes coronavirus disease 2019, or COVID-19). Gamma category- some avian species (IBV) [4]. Novel Corona belongs to the same category of SARS and MERS that showed the asymptomatic symptoms [1], [4], [5]. So, due to its initial asymptomatic behavior, Corona Virus also decided the terminology of human itself: H-Highly, U-Unhealthy, MMessenger \{of\}, A - Asymptomatic, N- Novel- COVID-19. 


\subsection{COMPARING CORONAVIRUS WITH OTHER SARS}

Human Corona was first spotted in the mid-1960s. A first Human coronavirus B814 was isolated by Tyrell and Bynoe from the respiratory tract of a person having symptoms of a common cold. Hamre and Procknow isolated 229E from medical student having a cold. OC43 by McIntosh et al and 229E were having the same morphology. A group of virologists were studying various strains of transmissible viruses including hepatitis, swine flu concluded the same morphology of them under an electron microscope in the late 1960s. These strains of Coronaviruses are associated with pneumonia in children and chronic bronchitis and critical illness in adults and elders. With time, in 2002 and 2003, a new strain of the SARS virus was emerged in China and spread worldwide. Out of it, Asia was worst affected by SARS. HLN63 was reported in 2004, HCoV HKU1 in 2005. Later, in 2012 another CoV emerged in the form of MERS- CoV in Saudi Arabia. It was located in Camel and transmitted to closely contact humans [6], [7], [8], [9], [10], [11], [12], [13], [14]. Now. In 2019, SARS- CoV-2 has evolved as a pandemic in China and still scares the world [15].(Figure 2)

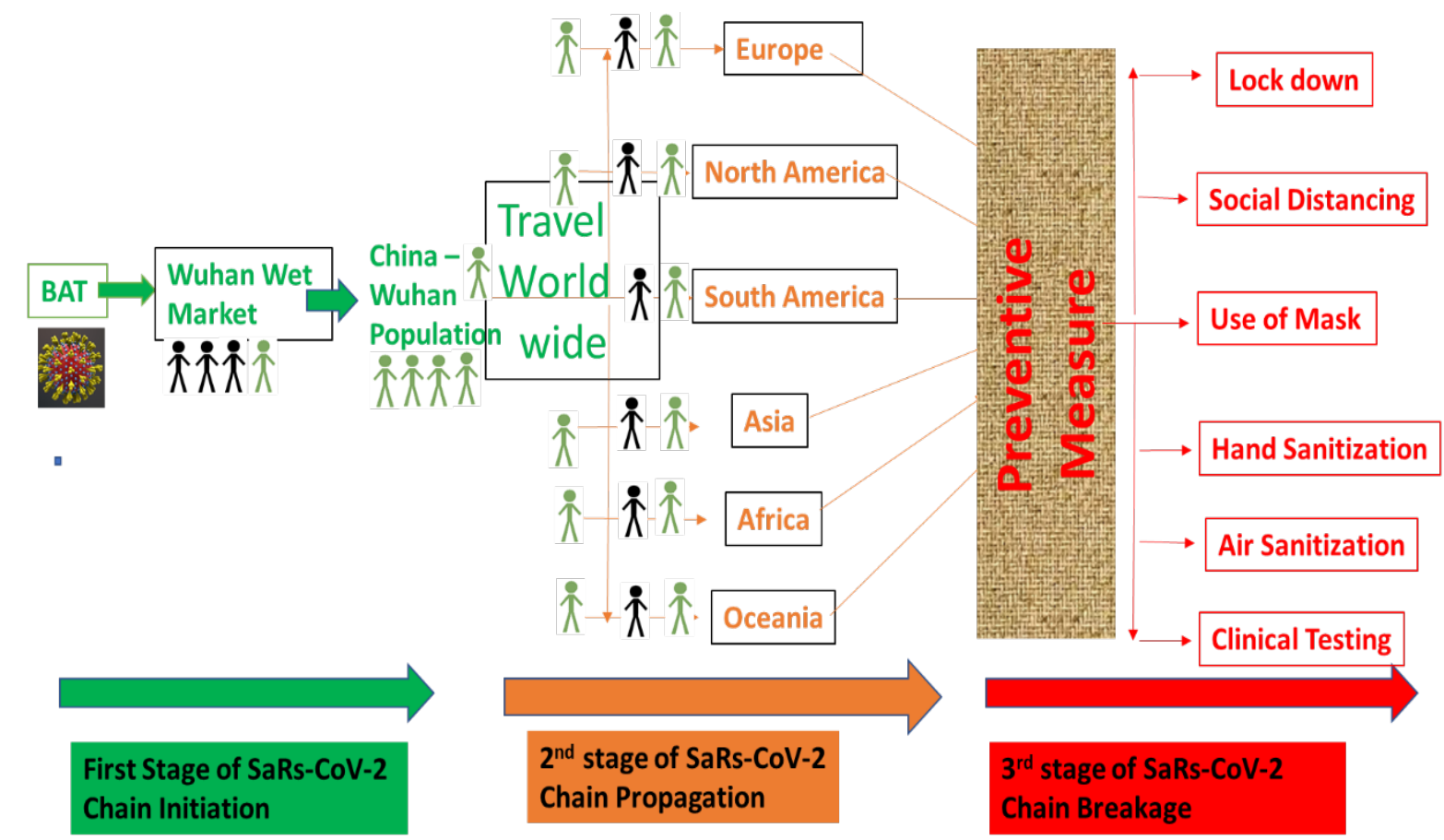

Figure 2: Flow chart shows the chain Virus from China wet market to other world countries and preventive measures used by Countries to stop the chain of COVID-19.

Modes of Transmission: Virus can transmit from animal to animal (Figure 3), animal to human, and human to human. 229E, NL63, OC43, HKU1, MERS-CoV, SARS-CoV, SARS-CoV2 These seven types of Viruses can infect the human race. 229E, NL63, OC43, HKU1 can directly infect the human and MERS-CoV, SARS-CoV, SARS-CoV2 are transmitted from animal to human. Duration in air, humidity, airborne transmission, duration on objects, Floor are the major routes of human to human transmission [16], [17], [18]. 


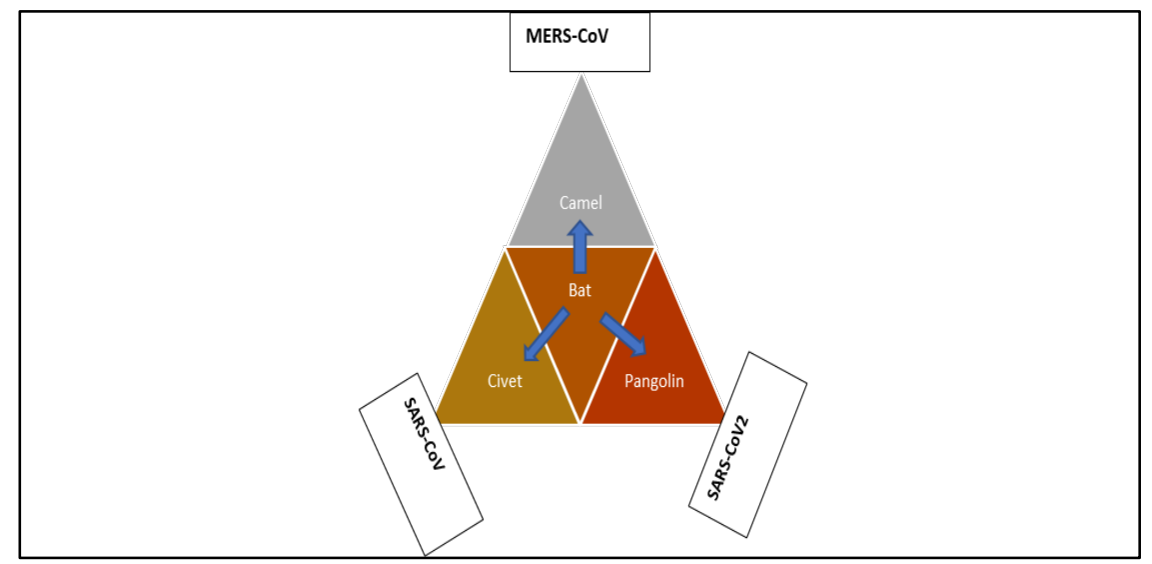

Figure 3: Represents the transmission of viruses from animal to animal.

Structure of virus: Corona Virus is a spherical pleomorphic microorganism having an average diameter of $120 \mathrm{~nm}$. Virus has 4 types of proteins: Spike (S protein), Envelope (E protein), Membrane (M protein), Nucleocapsid ( $\mathrm{N}$ protein). The structural and functional behavior of these proteins of virus study (from outer to inner part) are as follow. S protein named Spike plays an important role in infecting the host cells. Two types of spikes are there, first, the long projections on the surface of the virus consist of Glycoprotein having a length of $20 \mathrm{~nm}$. Second smaller spike, a Hemagglutinin esterase HE embedded in the envelope of the virus. HE has a property of invasion. It attaches and destructs the receptor sialic acid which is present on the surface of host cells. E protein, The Envelope represents the outer layer of the virus. It consists of bilayer lipid protein that infuses with the membrane of the infected host cell and releases nucleocapsid and genome into the host cell. It has an average diameter of $80 \mathrm{~nm}$. M protein is abundant in the envelope. $\mathrm{N}$-protein, the Nucleocapsid, are bound with a single-stranded RNA genome. [5], [19], [20]

How Virus works: Viruses are considered to be immortal due to their exponential multiplication rate per minute is higher than the mortal rate. Viruses have a budding process, the budded parents' cells shed more daughter virus particles into the environment to an extended period. Then the virus enveloped themselves into the lipid membrane and remain in search of new hosts for further replication ${ }^{5}$. The lipid membrane of the virus attaches to the lipid membrane of the host cell. Inside the infected host cell, the virus injects its genetic material to order the infected cell to release the enzyme for producing new virus particles. These new virus particles assemble themselves and break the infected cell and get free itself for the next cell for establishing the virus factory.

Symptoms: At the early stage of infection, people may or may not be sick. Virus uses the incubation period of 14 days [1] (usually an average of 5 days) to shows the first symptom in infected people. Why medical practitioners are concerned with fever and dry cough as a signal of an infected person, because the symptom like fever a respondent of the immune system of the host body to alarming the rest of the body by producing chemical cytokines and dry cough shows the irritation of infected cells of lungs. Some major and less common symptoms have been observed in COVID-19 infectious peoples. Virus shows different symptoms in different people. Clinically tested reports show fever, dry cough, dyspnoea, chest pain, fatigue, and myalgia as major symptoms and less common symptoms include headache, dizziness, abdominal pain, diarrhea, nausea, and vomiting. Severe symptoms, which lead to fatal are shortness of breath, chest pain, loss of speech and movement, severe pneumonia. The study of $2 \%$ cases globally [21], shows that virus prefers to attack on the lower respiratory tract rather than upper respiratory tract as critical illness stage. The first two patients age 61 \& 69 died in Wuhan, China due to acute respiratory distress syndrome (ARDS) [7], [22], [23], [24], [25], [26], [27], [28].

\section{FACTORS INFLUENCING CORONAVIRUS}

Weather Conditions, host defence mechanism, age of host, contact period etc. are the factors that affect the virus activity. Weather conditions like low temperature and low humidity markedly increases the viability of COVID-19 on contaminated surfaces [29].Major cases of SARS- CoV have emerged in the season of November to March 2003 and 2005. Same with SARS CoV-2, the first case was reported in December 2019 and keeps on increasing with a chain of infection worldwide even in running year 2020. More air-conditioned areas like hospitals [30], [31], [32], [33], community centers, shopping malls, etc. increases the survival of viruses from days to weeks and from dry to liquid 
Rajpreet Kaur, and Dr. Anita Gupta

surfaces respectively. In these areas, a single droplet in the environment provides a pathway for transmission of infection from human to human and also increases the rapid growth of the activity of the SARS virus. Droplet size decides either to settle down on the surfaces of material to contaminate or remains in the air to inhale by the susceptible host. The estimated viability of SARS CoV-2 on dry surfaces using a Bayesian regression model on the conducted experiment was from 4 hours to a maximum of 72 hours [15]. SARS CoV-1 and SARS CoV-2 have close aerosol and surface stability related to the environment [34],but still stability process of SARS viruses in the environment is unknown. From literature, it has been seen that effective temperature range from 29- 32 degree has high discomfort on SARS viruses and provide extreme instability on the temperature range of 32 -36 degree [29]. When exposed to a temperature of 56 degree for 15 mins, it reduces the stability and even kills the virus. The host defence mechanism is related to the immune system of host targeted by COVID-19 [28]. Prolonged diseased persons like diabetic, cardiovascular, asthmatic are more susceptible to COVID-19 attack because of the weak defence of the immune system. [35], [36], [37]

\section{COVID: A DAREDEVIL}

COVID-19 virus has forced many countries to declare it a national emergency, giving strict guidelines and mandate to "Stay Home - Stay Safe", wear a mask, observe social distancing, avoid social gatherings, avoid public transport, sports complex, clubs etc.

WHO declared COVID -19 a pandemic, which shows that this virus has the potential to affect an exceptionally large population in the world. The most frightening fact is that Coronavirus can survive for years without living because it is a sphere of genetic material having spiky/thorny protein shell. By entering into our respiratory system this virus can capture our cells and can create millions of its replicas. The extent of its wickedness is that many times it sits silently (person remains asymptomatic) in a host and keeps spreading like a ghost. When the virus finds a host, it uses the proteins on its surface to unbolt and occupy a decent space in its host living cell. Thus, the molecular machinery of the host is seized. Its larger size (three times bigger and heavier than pathogens responsible for dengue, Zika, and West Nile) and relative sophistication in action, makes it more toxic, deadly, poisonous, lethal. It multiplies itself at a fast rate (can make approximate 10,000 imitations in a few hours). White Blood Cells in an infected body start producing antibodies in large numbers to combat the attack.

\section{COVID: Dominant on mankind}

Why only running water is not necessary: Because COVID-19 is an enveloped virus with a bilayer of lipid membrane with protein spikes. It acts like a grease that sticks with the skin surface. Due to non- interaction between polar(water) and nonpolar (lipid membrane) components, the virus remains intact with the skin, and water just simply runs out from the hand.

Corona infection Chain Transmission from Human to Human: Coronavirus follows the chain transmission process (Figure 4) to rule the world. Can we say Coronavirus as dangerous as the Nuclear fission process? Yes, I can say. Because both follows the chain process and sustains itself. Three steps are involved in the chain process. FirstChain Initiation, Second- Chain Propagation, Third- Chain termination.

Chain Initiation: In nuclear fission process initiation, Neutron is bombarded to ${ }^{235} \mathrm{Ur}$ to produce two unstable nuclei and three neutrons. Like-wise this, Initially, coronavirus was bombarded by animals (Eg: Bat, Camel) to Humans in China in a form of MERS- CoV, SARS-CoV, recent SARS- CoV-2.

Chain Propagation: In Chain propagation step of nuclear fission. Daughter neutrons attack the uranium fuel to produce more neutrons and isotopes. Same COVID-19 virus replicates in the infected person and spread in the air by sneezing, coughing, open breathing of infected person, and even touch of contagious surfaces. New host human acts as fuel for the virus for their exponential growth to explode. Airborne transmission plays an important role in the transmission of COVID-19 from human to human by contaminated surfaces [16].

Chain Termination: In the chain termination step of nuclear fission, Control rods are used to absorb the neutrons. To terminate the chain reaction of COVID-19, some control measures are applied by WHO like Handwashing with soap, Sanitization, Use of disinfection Spray, Strict Lockdown [38]. Also, Worldwide Scientists, Researchers are burning their days and nights for exploring the vaccine against this nuclear COVID-19 [39]. 


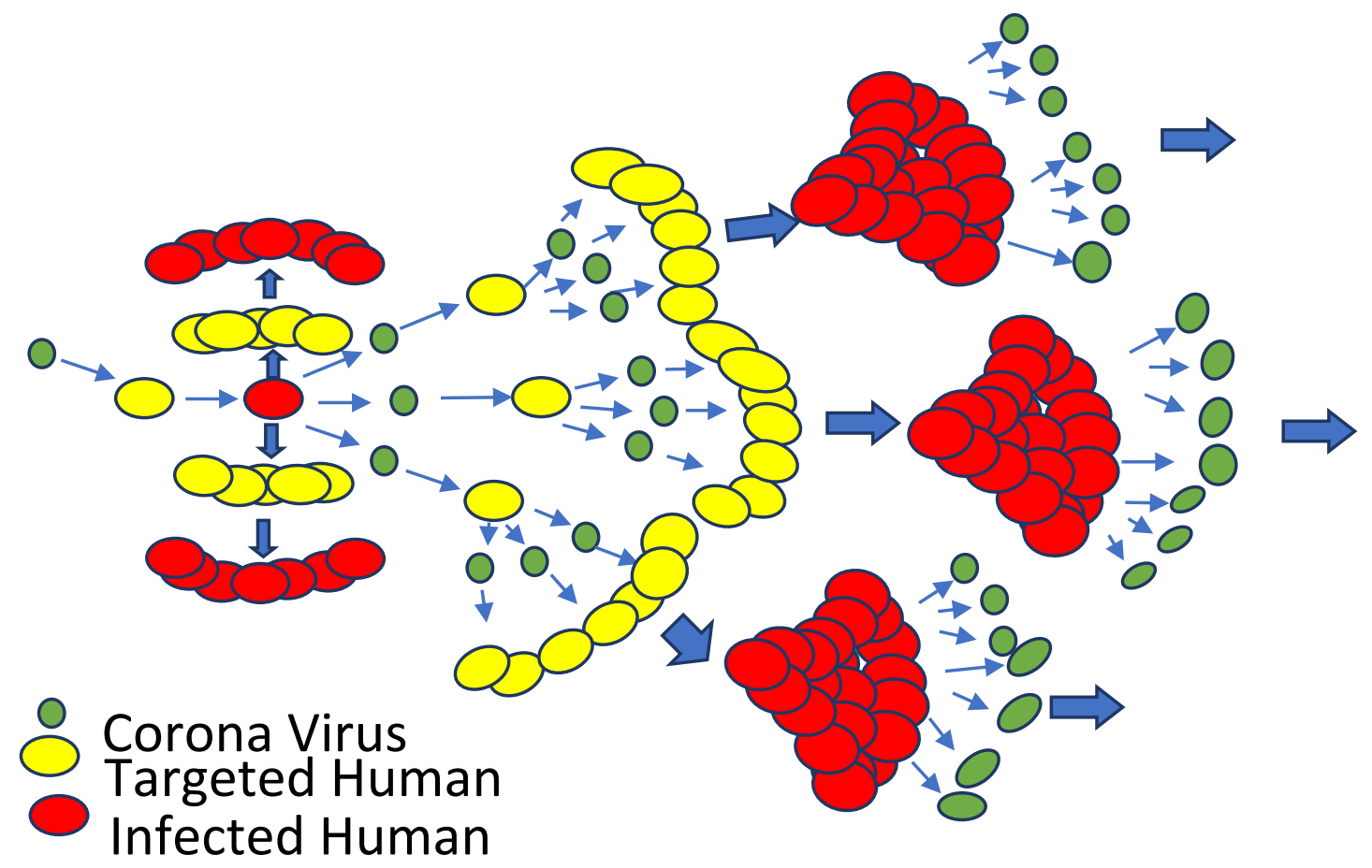

Figure 4: Represents the Chain Transmission of asymptomatic COVID-19 from human to human.

COVID pandemic in INDIA: This on-going India's fight against this invisible enemy is a great battle in which our country had tried to flatten the curve of infection, by observing strict lockdown and mass awareness regarding precautions. The toll in India is too low, compared to all SAARC countries, evident the success of efforts, a half battle is won by preventing community spread till date, prevented immense burden on health care system so that we can buy time in hope of an effective drug development which might save millions of precious lives [40].

India has taken countless measures like travel visas stand suspended, all schools, colleges, cinema halls, stadiums, sports clubs, public clubs will remain shut. Mega drive of disinfecting all public places, private offices, shopping malls, sanitization of public transport vehicles, and terminals was carried out. Mammoth efforts to procure full quarantine body kits and spray machines were carried on an urgent basis to prevent the spread. The real assessment of the effectiveness of measures would come one year down the line when we count the number of deaths per million of the population in each country. Hope India would excel in that too.

India has many challenges like dense population, crowded places in urban areas, poor access to medical facilities in rural areas, large population below poverty line, lack of awareness, huge daily wagers and their dependent family members, narrow supply of equipment, inadequate food supply chain etc [41], [42]. The updated confirmed number of corona cases in India is 6,473,544, recovered cases 5,427,706, total death cases are 100,875. [43]

Golden rules of Handwash: Hand hygiene resources play a significant role in infection prevention and control [44], [45], [46], [47], [48]. 5th May is celebrated as Hand Hygiene Day by WHO. UNESCO, The UN organization also in support of Chemistry [49], as basic Science teaches the Science behind Handwashing to battle with COVID-19. In the context of the present situation, we cannot ignore the basic science as 'Our future is based on it.' Washing your hands with soap can save millions of lives in today's scenario. Viruses are so tiny in size that they often need mechanical and chemical action to remove the sticky microorganisms out of the crevices of the skin. Rubbing soap for 20 seconds continuously will result in penetrating the protecting oily lipid membrane of the virus. The soap/surfactant molecules have dual behavior as they are composed of hydrophilic and hydrophobic parts. The hydrophilic head reaches out to bond with water, while the hydrophobic tail turns inwards and scoop up bacteria/ virus which they catch in tiny soap bubble cages called Micelles. (Figure 5).

The hydrophobic tail can bond with oil and fats will pierce the COVID-19 virus and break it into RNA cells which can no further attack the human respiratory system [50], [51], [52], [53]. 
The regular soap will do the roles and responsibilities properly, with no room for the antibacterial soap and gels. The antibacterial products do not have any specific effect on the virus at all.

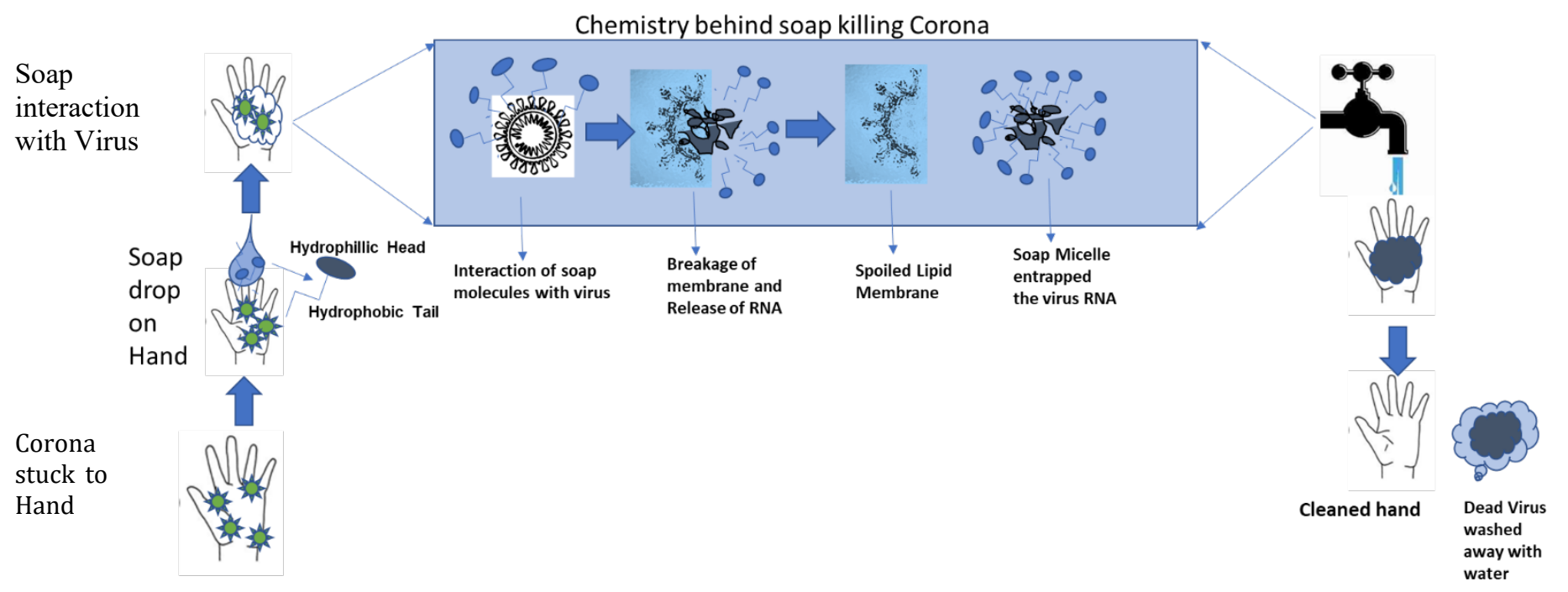

Figure 5: Represents How handwashing with soap is battling against Corona.

Role of Surfactant Micelles in Sanitization: Nature also uses the process of micelles for their metabolic activity. Even in human body surfactants are produced e.g. Pulmonary (Lung) surfactant, which is a Lipoprotein complex having both Hydrophilic and hydrophobic parts. Dipalmitoyl phosphatidylcholine (DPPC) lipid is a major component that reduces the surface tension and SP-A, SP-D act as Collectins, inborn immunity against foreign particles, SP-B, and SP-C are hydrophobic membrane proteins, which regulate the rate of spread of surfactant on the surface. These proteins act synergistically to enrich the DPPC on the air-water interface of alveoli for the functioning of the lungs [54], [55], [56], [57]. Another natural surfactant- Glycocholic acid (Bile acid), which is a composition of hydrophilic glycine group and hydrophobic cholic acid group. Bile acid act as a surfactant on the lipid/water interface to form micelles. Bile acid micelles suspended in the chyme, enclose nutrients for their absorption in the body [58], [59], [60].

Surfactants are the surface-active agents [61], [62] function as a wetting agent [63], [64], Foaming agent [65], emulsifier [62], [63], [64], dispersants [62], [67]. Surfactant's micellar structure acts as a working module for cleaning of particles [63], [64], [68], [69], [70], [71] like dust, bacteria, viruses, etc from skin surface. Surfactant operates by breaking down the interface between water and oil/dirt [72]. Surfactants have the hydrophilic and hydrophobic portions. Surfactants can help in the opening of Coronavirus particles. Also, Surfactant encapsulates these viral molecules [73] inside a cage-like structure known micelles, which are suspended in lather produced on a surface by soap and water. In this way the viral material can be effectively deactivated and washed away from the surface. Whenever a COVID-19 infected person breathes, sneeze, cough, or allow saliva droplets to fall while talking then these viruses can enter the body of other healthy people through eyes, nose, or mouth. Other contaminated objects [70] in surroundings can also act as virus carriers because the virus can survive on some surface for long hours in the wait of some host cell.

These contaminated objects can transport viral infections whenever some touch face/nose/mouth after touching such objects. Hand-washing is the best way to protest against COVID-19. The gold standards of washing hands involve proper rubbing of hands thoroughly with soap and water for 20 seconds continuously which should result in lather formation.

The hydrophobic part of the surfactant avoids water and promptly interacts with any biological material/oil/fats-which makes the outer membrane [61] of Coronavirus. This pin-like surfactant molecule would encapsulate the viral molecule in micelles. This would result in solubilizing the nearly insoluble viral molecule and help us get rid of the COVID-19 virus from our hands. For the effectiveness of soap, lather must cover palms, fingernails, in-between the fingers, and wrinkles/crevices on skin. Using any other disinfectant or sanitizer for hands, 
might kill germs but would not remove them from the skin surface. All types of soaps can do this job, including the basic soaps.

Surfactants are broadly classified as Anionic surfactants (alkyl sulfates, alkylbenzene sulfonates, alkyl ether sulfates, alkyl sulfates); Cationic Surfactants (Esterquats, monoalkyl quaternary systems, -QACs, Double alkyl quaternary system- Gemini); Non-ionic Surfactant (ethoxylates, polysorbates); Amphoteric Surfactant (Trimethyl glycine); Natural Biosurfactants (Pulmonary surfactant, Glycocholic acid (Bile Acid), Lecithin, Cephalin [74]. Almost all cleansing products are surfactant based. A recent study has suggested that Alcohol-free sanitizers if made surfactant-based then they can quite effectively fight against COVID-19 spread. [75], [76], [77], [78]

To contain the spread of COVID-19, we need to disinfect skin, surfaces (like chair, tables, laptops, mobile phones, remote devices, tetra packs etc.). The use of soap and water is limited to availability, the circumstances, and context. Thus, we should encourage the use of biosurfactants and become environmentally responsible, use alcohol-free sanitizers which are easy on the skin.

Also, Quaternary ammonium compound surfactant [79] (QACs)- single chain commercial surfactants are preferred majorly as cleaner and disinfectant from the early 19's because of high stability, surface activity, compatibility with other ingredients, and no odor. They are effective against most vegetative bacteria and enveloped viruses and some fungi [79], [80], [81], [82], [83]. 0.05\% to $2 \%$ for the concentration of QACs contacted with particles for 10 mins can work to disinfect the surface. QACs have evolved from the older generation to the fifth generation with their advanced working module. This fifth-generation QACs is a composition of fourth and secondgeneration QAC that is, di decyl dimethyl ammonium chloride + alkyl dimethyl ammonium chloride, alkyl benzyl ammonium dimetiletilbencil + of other varieties according to the formulations, which is having both properties of remain active in hard water and biocidal activities and safe to use. QAC with bromide counter-anions are more effective than chloride ions. The working module of QACs based upon disrupt the outer cell membrane of microorganism, unload the internal cell constituents, engulf it in its micellar structure and moved away [84].

Gemini Surfactant: Some reported surfactants are also commercially available now in the market under the name Gemini surfactants, which hold the $50 \%$ share of surfactant market. Gemini surfactants are much more preferred over conventional single tail QAC surfactants and other surfactants because of their properties like low CMC, solubility, Kraft point, High hydrophobicity, in range Hydrophilicity/lipophilicity (HLB) value, micelles formation, good self-aggregation, and effective antimicrobial activity [74], [85]. Structurally, Gemini surfactants are double-tailed with the ionic head group separated by the spacer. An ionic head group can be classified as cationic, anionic, non-ionic and zwitterionic. Various Gemini surfactants [86] are available in the market by changing in alkyl chain length, head group, and change in spacer length. The general formula of Gemini surfactant is $m-s-m$, where $m$ stands for alkyl chain ranges from $\left(-\mathrm{CH}_{3}\right)_{12}$ to $\left(-\mathrm{CH}_{3}\right)_{18}$ and $s$ stands for spacer number from 2 to 12 . These dimeric structures form better lather by decreasing their interfacial tension (IFT). Hydrophobicity of Gemini surfactant can be increased by increasing their hydrophobic chain length and their hydrophilic head group leads to further increase their HLB level. This high HLB level is good for the removal of oil/lipid [85] particles from surfaces than conventional single-tailed surfactant. As reported in the literature, 6-9 range of HLB value is considered good for the removal of oil/lipids from surfaces [87], [88], [89], [90]. High content of hydrophilicity up to the range of 40 just increases the dissolution of surfactant molecules in water but decreases the power of attachment with the surfaces by increasing the interfacial tension. Instead of this, a double chain hydrophobic tail also decreases the solubility of the surfactant in water. In support of this, low CMC value and kraft value is major responsible for low concentration usage of surfactant with high applicability which favors the low-cost economic sale value. As the coronavirus is a double-layered lipid membrane particle, Gemini surfactants are proposed to be good for the disruption and removal of virus particles from the skin surface due to the high hydrophobicity effect that vitals for interacting non-polar surfaces by displacing the polar molecules away. Still there is a need for more findings on it.Factor like chain length, number of tails, head group, spacer length, temperature, ionic strength, additive, etc affects the micellization propertyand antimicrobial activity of surfactant [91], [92], [93]. CMC micellization and aggregation number [52], [94] properties depend upon temperature. The dissolution of nonpolar substances is related to the thermodynamic stability of the surfactant solution. High temperature could be supposed to increase the activity of surfactant on viruses [51], [53], because, at high temperature, viruses and surfactant plays a reverse role in their activity. At high temperature, distortion of water molecules with a decrease in hydrogen bonding further decreases the CMC of the surfactant molecules. This increases the molecular aggregation number of non-ionic surfactants in aqueous solution. Larger the hydrophobic chain group, larger the micellar core result to larger solubilization of 
Rajpreet Kaur, and Dr. Anita Gupta

nonpolar substances. In the ionic surfactant, the addition of inorganic salt in aqueous solution decreases the CMC due to a decrease in electrostatic repulsive forces between the hydrophilic group of surfactants, increases the dissolution of nonpolar substances in micellar cores. CMC and interfacial property of surfactants are also affected by the spacer methylchain length. CMC increases with shorter spacer length up to 4 carbon chain, and remain extended in the air-water interface. But as the spacer length increases CMC decreases which further makes the molecule flexible and more hydrophobic. A long length spacer fold at air-water interface and penetrates easily to the cell membrane of microbes. The high hydrophobic content makes the Gemini surfactant less biodegrable, but it can be replaced by the use of amino-acid based Gemini surfactant up to $60 \%$ and sugar substituted Gemini surfactant like geminialkyldeoxy-D-glucitolammonium salts up to 20-32\%. Even with ester bond containing gemini surfactants are more easily biodegradable.[62], [74], [95], [96], [97]

Disinfects for Non-living Materials: To control the airborne transmission, sanitation of air and non- living materials is necessary. Sanitation program was first introduced in the early 18's by Ignaz Semmelweiss in his Viennese Hospital. He added the role of hand sanitization, surfaces sanitization, equipment sanitization in laboratory to disinfect of microbial infection. Further, in the 1860s John Lister introduced the chemical control of infections. He also popularized the use of phenol as an infection inhibitor. In 1827 and 1894, Use of chlorine and hypochlorites for water treatment was recommended in England. Disinfectant plays an important role in breaking the chain of transmission of infectious microbes. Various chemicals like chlorine, iodine, silver nitrate, phenols, and alcohol were used as chemical disinfectants for cleaning of skin injuries, wounds, and contaminated surfaces. In 20th century the foundation of rules and principles was laid on disinfectant testing and working. Later on, various chemicals as disinfectants are organized to serve the society in various field [98], [99]. Chemical disinfectants - Chloroxylenol (4.5-5.5\%)/ Benzalkonium Chloride, 1\% Sodium hypochlorite, Alcohol, phenol [83] can easily wipe out the settled particles of COVID- 19 from the environment. Various guidelines have been implemented to clean the common public areas like indoor, outdoor, and public toilets. These areas have a fair chance of spreading the Coronavirus. To control the spread of the virus by contaminated surfaces $1 \%$ sodium hypochlorite solution is used by the cleaners. Guidelines for preparation (volume/volume solution, weight/volume solution ratio) of $1 \%$ sodium hypochlorite solution are, 1 part of sodium hypochlorite - liquid bleach (3.5\% chlorine range) with 2.5 parts of water, 1 part of Sodium hypochlorite-liquid ( $5 \%$ chlorine range) with 4 parts of water, 17 grams of Sodium dichloroisocyanurate (NaDCC powder with $60 \%$ chlorine range) in 1 liter of water, 11 NaDCC- tablets( $60 \%$ chlorine) to 1 liter water, $80 \mathrm{~g}$ Chloramine-powder(25\% chlorine) to 1 liter of water, $7 \mathrm{~g}$ of Bleaching powder(70\% chlorine range) to 1 liter water [100]. $70 \%$ alcohol is used to disinfect the metal surfaces. Various studies have been done by researchers on ozone therapy [101], [102], [103], [104] for bio-disinfectant in various countries. It is proven that ozone has virucidal properties, and also acts as a low-cost disinfecting agent, but due to lack of approved standard air treatment protocol, it is still not strategized to control the virus outbreak. In 19 century, ozone is already used for the treatment of drinking water. Ozone therapy also known as 'medical ozone' is well known for curing 114 diseases including cancer, HIV-AIDS, and SARS. The composition of ozone therapy includes 1-5\% ozone and 95-98\% oxygen. For sanitization of air, gaseous disinfectant is more preferred over liquid disinfectant due to high diffusion rate, high oxidizing power, high penetration power. Also. Ozone technology is used for cleaning of vegetables and fruits [105], [106] by purifier industries. Aerosolization of ozone with less concentration requires less time to react with microbes suspended in air and water. It diffuses more easily to each corner of the surface and environment. Ozone, the energy-rich molecule reacts with proteins, protein functional groups, amino acid, a nucleic acid with a much faster rate than chlorine. The interaction mechanism of ozone inactivates the activity of various microbes like fungi, bacteria, yeast, viruses including SARS strains including 2019-nCoV. Like other microbes, coronavirus is enriched in protein including its spikes and envelope. Ozone kills viruses by oxidizing the membrane proteins, damaging the virus genetic material. Virus does not replicate outside the living body. Without active genetic material, the chain of infection can be ruptured easily within the transmission period.

\section{CONCLUSION AND FUTURE PERSPECTIVE}

All Nations on the globe can stay together to fight with a common enemy, in a coordinated way. While fighting with the common enemy, we need to develop the vaccine for common good. The mega pharmaceutical companies shouldn't be producing vaccines as asocial business. An increasing demands of personal care products, detergents, 
cleaners and industrial-anticorrosion and biocidal-products, use of surfactants-based product are expected to lead to the more effective and innovative in future. To restrain the spread of this virus, Surfactant coated nanoparticles can be used for the treatment of coronavirus. MERS- CoV, and SARS-CoV is the first outbreak that impacted human loss and Socio-economic loss. Now, this SARS- CoV-2 also has the same impact on the earth. Humans should take lessons from past experiences of outbreaks to overcome the present situation. We all can consider this catastrophe as an opportunity to make things happen in a magnified way. Let's join hands by social distancing, use of masks to fight this pandemic by whatever means we can.

Let not Corona give us a permanent scar!

\section{SOURCES OF FUNDING}

This research received no specific grant from any funding agency in the public, commercial, or not-for-profit sectors.

\section{CONFLICT OF INTEREST}

The author have declared that no competing interests exist.

\section{ACKNOWLEDGMENT}

I would like to acknowledge the WOS-B, KIRAN division, Department of science and technology (DST) for funding the project.

\section{REFERENCES}

[1] Lauer, S. A.; Grantz, K. H.; Bi, Q.; Jones, F. K.; Zheng, Q.; Meredith, H. R.; Azman, A. S.; Reich, N. G.; Lessler, J. The Incubation Period of Coronavirus Disease 2019 (COVID-19) From Publicly Reported Confirmed Cases: Estimation and Application. Annals of internal medicine2020. https://doi.org/10.7326/M20-0504.

[2] Press Briefing by Members of the President's Coronavirus Task Force | The White House https://www.whitehouse.gov/briefings-statements/press-briefing-members-presidents-coronavirus-taskforce/ (accessed May 20, 2020).

[3] Coronavirus Update (Live): https://www.worldometers.info/coronavirus/(accessed on 03/10/2020

[4] MA, J. Coronavirus (COVID-19): History, Current Knowledge and Pipeline Medications. International Journal of Pharmaceutics \& Pharmacology2020, 4 (1), 1-9. https://doi.org/10.31531/2581-3080.1000140.

[5] Gillim-Ross, L.; Taylor, J.; Scholl, D. R.; Ridenour, J.; Masters, P. S.; Wentworth, D. E. Discovery of Novel Human and Animal Cells Infected by the Severe Acute Respiratory Syndrome Coronavirus by Replication-Specific Multiplex Reverse Transcription-PCR. Journal of Clinical Microbiology2004, 42 (7), 3196-3206. https://doi.org/10.1128/JCM.42.7.3196-3206.2004.

[6] Geller, C.; Varbanov, M.; Duval, R. E. Human Coronaviruses: Insights into Environmental Resistance and Its Influence on the Development of New Antiseptic Strategies. Viruses. November 2012, pp 3044-3068. https://doi.org/10.3390/v4113044.

[7] Peiris, J. S. M.; Lai, S. T.; Poon, L. L. M.; Guan, Y.; Yam, L. Y. C.; Lim, W.; Nicholls, J.; Yee, W. K. S.; Yan, W. W.; Cheung, M. T.; Cheng, V. C. C.; Chan, K. H.; Tsang, D. N. C.; Yung, R. W. H.; Ng, T. K.; Yuen, K. Y. Coronavirus as a Possible Cause of Severe Acute Respiratory Syndrome. Lancet2003, 361 (9366), 1319-1325. https://doi.org/10.1016/S0140-6736(03)13077-2.

[8] Ksiazek, T. G.; Erdman, D.; Goldsmith, C. S.; Zaki, S. R.; Peret, T.; Emery, S.; Tong, S.; Urbani, C.; Comer, J. A.; Lim, W.; Rollin, P. E.; Dowell, S. F.; Ling, A. E.; Humphrey, C. D.; Shieh, W. J.; Guarner, J.; Paddock, C. D.; Roca, P.; Fields, B.; DeRisi, J.; Yang, J. Y.; Cox, N.; Hughes, J. M.; LeDuc, J. W.; Bellini, W. J.; Anderson, L. J. A Novel Coronavirus Associated with Severe Acute Respiratory Syndrome. New England Journal of Medicine2003, 348 (20), 1953-1966. https://doi.org/10.1056/NEJMoa030781.

[9] Woo, P. C. Y.; Lau, S. K. P.; Chu, C.; Chan, K.; Tsoi, H.; Huang, Y.; Wong, B. H. L.; Poon, R. W. S.; Cai, J. J.; Luk, W.; Poon, L. L. M.; Wong, S. S. Y.; Guan, Y.; Peiris, J. S. M.; Yuen, K. Characterization and Complete Genome Sequence 
of a Novel Coronavirus, Coronavirus HKU1, from Patients with Pneumonia. Journal of Virology2005, 79 (2), 884-895. https://doi.org/10.1128/jvi.79.2.884-895.2005.

[10] van der Hoek, L.; Pyrc, K.; Jebbink, M. F.; Vermeulen-Oost, W.; Berkhout, R. J. M.; Wolthers, K. C.; WertheimVan Dillen, P. M. E.; Kaandorp, J.; Spaargaren, J.; Berkhout, B. Identification of a New Human Coronavirus. Nature Medicine2004, 10 (4), 368-373. https://doi.org/10.1038/nm1024.

[11] Fouchier, R. A. M.; Hartwig, N. G.; Bestebroer, T. M.; Niemeyer, B.; de Jong, J. C.; Simon, J. H.; Osterhaus, A. D. M. E. A Previously Undescribed Coronavirus Associated with Respiratory Disease in Humans. Proceedings of the National Academy of Sciences of the United States of America2004, 101 (16), 6212-6216. https://doi.org/10.1073/pnas.0400762101.

[12] Esper, F.; Weibel, C.; Ferguson, D.; Landry, M. L.; Kahn, J. S. Evidence of a Novel Human Coronavirus That Is Associated with Respiratory Tract Disease in Infants and Young Children. The Journal of Infectious Diseases2005, 191 (4), 492-498. https://doi.org/10.1086/428138.

[13] Bradburne, A. F.; Bynoe, M. L.; Tyrrell, D. A. J. Effects of a "New" Human Respiratory Virus in Volunteers. British Medical Journal1967, 3 (5568), 767-769. https://doi.org/10.1136/bmj.3.5568.767.

[14] Almeida, J. D.; Tyrrell, D. A. The Morphology of Three Previously Uncharacterized Human Respiratory Viruses That Grow in Organ Culture. The Journal of general virology1967, 1 (2), 175-178. https://doi.org/10.1099/0022-1317-1-2-175.

[15] van Doremalen, N.; Bushmaker, T.; Morris, D. H.; Holbrook, M. G.; Gamble, A.; Williamson, B. N.; Tamin, A.; Harcourt, J. L.; Thornburg, N. J.; Gerber, S. I.; Lloyd-Smith, J. O.; de Wit, E.; Munster, V. J. Aerosol and Surface Stability of SARS-CoV-2 as Compared with SARS-CoV-1. The New England journal of medicine. NLM (Medline) April 16, 2020. https://doi.org/10.1056/NEJMc2004973.

[16] Ghinai, I.; McPherson, T. D.; Hunter, J. C.; Kirking, H. L.; Christiansen, D.; Joshi, K.; Rubin, R.; Morales-Estrada, S.; Black, S. R.; Pacilli, M.; Fricchione, M. J.; Chugh, R. K.; Walblay, K. A.; Ahmed, N. S.; Stoecker, W. C.; Hasan, N. F.; Burdsall, D. P.; Reese, H. E.; Wallace, M.; Wang, C.; Moeller, D.; Korpics, J.; Novosad, S. A.; Benowitz, I.; Jacobs, M. W.; Dasari, V. S.; Patel, M. T.; Kauerauf, J.; Charles, E. M.; Ezike, N. O.; Chu, V.; Midgley, C. M.; Rolfes, M. A.; Gerber, S. I.; Lu, X.; Lindstrom, S.; Verani, J. R.; Layden, J. E. First Known Person-to-Person Transmission of Severe Acute Respiratory Syndrome Coronavirus 2 (SARS-CoV-2) in the USA. The Lancet2020, 395 (10230), 1137-1144. https://doi.org/10.1016/S0140-6736(20)30607-3.

[17] Kucharski, A. J.; Russell, T. W.; Diamond, C.; Liu, Y.; Edmunds, J.; Funk, S.; Eggo, R. M.; Sun, F.; Jit, M.; Munday, J. D.; Davies, N.; Gimma, A.; van Zandvoort, K.; Gibbs, H.; Hellewell, J.; Jarvis, C. I.; Clifford, S.; Quilty, B. J.; Bosse, N. I.; Abbott, S.; Klepac, P.; Flasche, S. Early Dynamics of Transmission and Control of COVID-19: A Mathematical Modelling Study. The Lancet Infectious Diseases2020, 20 (5), 553-558. https://doi.org/10.1016/S1473-3099(20)30144-4.

[18] Chan, J. F. W.; Yuan, S.; Kok, K. H.; To, K. K. W.; Chu, H.; Yang, J.; Xing, F.; Liu, J.; Yip, C. C. Y.; Poon, R. W. S.; Tsoi, H. W.; Lo, S. K. F.; Chan, K. H.; Poon, V. K. M.; Chan, W. M.; Ip, J. D.; Cai, J. P.; Cheng, V. C. C.; Chen, H.; Hui, C. K. M.; Yuen, K. Y. A Familial Cluster of Pneumonia Associated with the 2019 Novel Coronavirus Indicating Personto-Person Transmission: A Study of a Family Cluster. The Lancet2020, 395 (10223), 514-523. https://doi.org/10.1016/S0140-6736(20)30154-9.

[19] Jin, Y.; Yang, H.; Ji, W.; Wu, W.; Chen, S.; Zhang, W.; Duan, G. Virology, Epidemiology, Pathogenesis, and Control of Covid-19. Viruses. MDPI AG 2020. https://doi.org/10.3390/v12040372.

[20] Kumar, D. Corona Virus: A Review of COVID-19. Eurasian Journal of Medicine and Oncology2020. https://doi.org/10.14744/ejmo.2020.51418.

[21] Worldometer. Coronavirus $\quad$ Cases. $\quad$ Worldometer. $\quad 2020, \quad$ pp $\quad 1-22$. https://doi.org/10.1101/2020.01.23.20018549V2.

[22] Huang, C.; Wang, Y.; Li, X.; Ren, L.; Zhao, J.; Hu, Y.; Zhang, L.; Fan, G.; Xu, J.; Gu, X.; Cheng, Z.; Yu, T.; Xia, J.; Wei, Y.; Wu, W.; Xie, X.; Yin, W.; Li, H.; Liu, M.; Xiao, Y.; Gao, H.; Guo, L.; Xie, J.; Wang, G.; Jiang, R.; Gao, Z.; Jin, Q.; Wang, J.; Cao, B. Clinical Features of Patients Infected with 2019 Novel Coronavirus in Wuhan, China. The Lancet2020, 395 (10223), 497-506. https://doi.org/10.1016/S0140-6736(20)30183-5.

[23] Jiang, F.; Deng, L.; Zhang, L.; Cai, Y.; Cheung, C. W.; Xia, Z. Review of the Clinical Characteristics of Coronavirus Disease 2019 (COVID-19). Journal of General Internal Medicine. Springer May 1, 2020. https://doi.org/10.1007/s11606-020-05762-w. 
[24] Department of Error: Clinical Features of Patients Infected with 2019 Novel Coronavirus in Wuhan, China (The Lancet (2020) 395(10223) (497-506), (S0140673620301835), (10.1016/S0140-6736(20)30183-5)). The Lancet. Lancet Publishing Group February 15, 2020, p 496. https://doi.org/10.1016/S01406736(20)30252-X.

[25] Wong, G.; Liu, W.; Liu, Y.; Zhou, B.; Bi, Y.; Gao, G. F. MERS, SARS, and Ebola: The Role of Super-Spreaders in Infectious Disease. Cell Host and Microbe. Cell Press October 14, 2015, pp 398-401. https://doi.org/10.1016/j.chom.2015.09.013.

[26] Zaki, A. M.; van Boheemen, S.; Bestebroer, T. M.; Osterhaus, A. D. M. E.; Fouchier, R. A. M. Isolation of a Novel Coronavirus from a Man with Pneumonia in Saudi Arabia. New England Journal of Medicine2012, 367 (19), 1814-1820. https://doi.org/10.1056/NEJMoa1211721.

[27] Zhu, N.; Zhang, D.; Wang, W.; Li, X.; Yang, B.; Song, J.; Zhao, X.; Huang, B.; Shi, W.; Lu, R.; Niu, P.; Zhan, F.; Ma, X.; Wang, D.; Xu, W.; Wu, G.; Gao, G. F.; Tan, W. A Novel Coronavirus from Patients with Pneumonia in China, 2019. New England Journal of Medicine2020, 382 (8), 727-733. https://doi.org/10.1056/NEJMoa2001017.

[28] Frieman, M.; Baric, R. Mechanisms of Severe Acute Respiratory Syndrome Pathogenesis and Innate Immunomodulation. Microbiology and Molecular Biology Reviews2008, 72 (4), 672-685. https://doi.org/10.1128/mmbr.00015-08.

[29] Chan, K. H.; Peiris, J. S. M.; Lam, S. Y.; Poon, L. L. M.; Yuen, K. Y.; Seto, W. H. The Effects of Temperature and Relative Humidity on the Viability of the SARS Coronavirus. Advances in Virology2011, 2011. https://doi.org/10.1155/2011/734690.

[30] Darnell, M. E. R.; Subbarao, K.; Feinstone, S. M.; Taylor, D. R. Inactivation of the Coronavirus That Induces Severe Acute Respiratory Syndrome, SARS-CoV. Journal of Virological Methods2004, 121 (1), 85-91. https://doi.org/10.1016/j.jviromet.2004.06.006.

[31] Esposito, S.; Bosis, S.; Niesters, H. G. M.; Tremolati, E.; Begliatti, E.; Rognoni, A.; Tagliabue, C.; Principi, N.; Osterhaus, A. D. M. E. Impact of Human Coronavirus Infections in Otherwise Healthy Children Who Attended an Emergency Department. Journal of Medical Virology2006, 78 (12), 1609-1615. https://doi.org/10.1002/jmv.20745.

[32] Falsey, A. R.; Walsh, E. E.; Hayden, F. G. Rhinovirus and Coronavirus Infection-Associated Hospitalizations among Older Adults. The Journal of Infectious Diseases2002, 185 (9), 1338-1341. https://doi.org/10.1086/339881.

[33] Chiu, S. S.; Hung Chan, K.; Wing Chu, K.; Kwan, S. W.; Guan, Y.; Man Poon, L. L.; Peiris, J. S. M. Human Coronavirus NL63 Infection and Other Coronavirus Infections in Children Hospitalized with Acute Respiratory Disease in Hong Kong, China. Clinical Infectious Diseases2005, 40 (12), 1721-1729. https://doi.org/10.1086/430301.

[34] Chen, Y. C.; Huang, L. M.; Chan, C. C.; Su, C. P.; Chang, S. C.; Chang, Y. Y.; Chen, M. L.; Hung, C. C.; Chen, W. J.; Lin, F. Y.; Lee, Y. T.; Chen, D. S.; Lee, Y. T.; Teng, C. M.; Yang, P. C.; Ho, H. N.; Chen, P. J.; Chang, M. F.; Wang, J. T.; Kao, C. L.; Wang, W. K.; Hsiao, C. H.; Hsueh, P. R. SARS in Hospital Emergency Room. Emerging Infectious Diseases2004, 10 (5), 782-788. https://doi.org/10.3201/eid1005.030579.

[35] Wu, A.; Peng, Y.; Huang, B.; Ding, X.; Wang, X.; Niu, P.; Meng, J.; Zhu, Z.; Zhang, Z.; Wang, J.; Sheng, J.; Quan, L.; Xia, Z.; Tan, W.; Cheng, G.; Jiang, T. Genome Composition and Divergence of the Novel Coronavirus (2019$\mathrm{NCoV}$ ) Originating in China. Cell Host and Microbe2020, 27 (3), 325-328. https://doi.org/10.1016/j.chom.2020.02.001.

[36] Stöhr, K. A Multicentre Collaboration to Investigate the Cause of Severe Acute Respiratory Syndrome. Lancet. Elsevier Limited May 17, 2003, pp 1730-1733. https://doi.org/10.1016/S0140-6736(03)13376-4.

[37] Zou, L.; Ruan, F.; Huang, M.; Liang, L.; Huang, H.; Hong, Z.; Yu, J.; Kang, M.; Song, Y.; Xia, J.; Guo, Q.; Song, T.; He, J.; Yen, H. L.; Peiris, M.; Wu, J. SARS-CoV-2 Viral Load in Upper Respiratory Specimens of Infected Patients. New England Journal of Medicine. Massachussetts Medical Society March 19, 2020, pp 1177-1179. https://doi.org/10.1056/NEJMc2001737.

[38] Infection prevention and control https://www.who.int/emergencies/diseases/novel-coronavirus2019/technical-guidance/infection-prevention-and-control (accessed May 21, 2020).

[39] Scientific Challenges for a safe Covid-19 Vaccine, Health News, ET HealthWorld https://health.economictimes.indiatimes.com/news/industry/scientific-challenges-for-a-safe-covid-19vaccine/75595176 (accessed May 21, 2020). 
[40] Commendable That India Able To keep COVID-19 Cases Low: WHO's Chief Scientist https://www.outlookindia.com/website/story/india-news-commendable-that-india-able-to-keep-covid19-cases-lower-than-other-nations-whos-chief-scientist/352541 (accessed May 21, 2020).

[41] COVID-19: A Bigger Challenge to the Indian Healthcare System - Developing Economics https://developingeconomics.org/2020/04/13/covid-19-a-bigger-challenge-to-the-indian-healthcaresystem/ (accessed May 21, 2020).

[42] Every state a country: Huge population makes India's Covid-19 fight bigger than nations put together - India News https://www.indiatoday.in/india/story/coronavirus-cases-india-states-population-comparisoncountries-graphic-1668354-2020-04-18 (accessed May 21, 2020).

[43] COVID-19 Corona Tracker https://www.coronatracker.com/ (accessed October 3, 2020).

[44] The Golden Rules for Hand Hygiene Best Practices.

[45] Akyol, A.; Ulusoy, H.; Özen, I. Handwashing: A Simple, Economical and Effective Method for Preventing Nosocomial Infections in Intensive Care Units. Journal of Hospital Infection. W.B. Saunders Ltd 2006, pp 395405. https://doi.org/10.1016/j.jhin.2005.10.007.

[46] Randle, J.; Clarke, M.; Storr, J. Hand Hygiene Compliance in Healthcare Workers. Journal of Hospital Infection. November 2006, pp 205-209. https://doi.org/10.1016/j.jhin.2006.06.008.

[47] Creedon, S. A. Healthcare Workers' Hand Decontamination Practices: Compliance with Recommended Guidelines. Journal of Advanced Nursing2005, 51 (3), 208-216. https://doi.org/10.1111/j.13652648.2005.03490.x.

[48] Kampf, G. The Six Golden Rules to Improve Compliance in Hand Hygiene. Journal of Hospital Infection2004, 56 (SUPPL. 2), 3-5. https://doi.org/10.1016/j.jhin.2003.12.023.

[49] How Soap Kills COVID-19 on Hands https://en.unesco.org/news/how-soap-kills-covid-19-hands (accessed May 21, 2020).

[50] Chao, W. C.; Shen, J. Y.; Lu, J. F.; Wang, J. S.; Yang, H. C.; Wee, K.; Lin, L. J.; Kuo, Y. C.; Yang, C. H.; Weng, S. H.; Huang, H. C.; Chen, Y. H.; Chou, P. T. Probing Water Environment of Trp59 in Ribonuclease T1: Insight of the Structure-Water Network Relationship. Journal of Physical Chemistry B2015, 119 (6), 2157-2167. https://doi.org/10.1021/jp503914s.

[51] Ray, D.; Kundu, A.; Pramanik, A.; Guchhait, N. Exploring the Interaction of a Micelle Entrapped Biologically Important Proton Transfer Probe with the Model Transport Protein Bovine Serum Albumin. Journal of Physical Chemistry B2015, 119 (6), 2168-2179. https://doi.org/10.1021/jp504037y.

[52] Tolen, T.; Ruengvisesh, S.; Taylor, T. Application of Surfactant Micelle-Entrapped Eugenol for Prevention of Growth of the Shiga Toxin-Producing Escherichia Coli in Ground Beef. Foods2017, 6 (8), 69. https://doi.org/10.3390/foods6080069.

[53] Weiss, J.; McClements, D. J. Mass Transport Phenomena in Oil-in-Water Emulsions Containing Surfactant Micelles: Solubilization. Langmuir2000, 16 (14), 5879-5883. https://doi.org/10.1021/la9914763.

[54] Mirastschijski, U.; Schwab, I.; Coger, V.; Zier, U.; Rianna, C.; He, W.; Maedler, K.; Kelm, S.; Radtke, A.; Belge, G.; Lindner, P.; Stahl, F.; Scharpenberg, M.; Lasota, L.; Timm, J. Lung Surfactant Accelerates Skin Wound Healing: A Translational Study with a Randomized Clinical Phase I Study. Scientific Reports2020, 10 (1). https://doi.org/10.1038/s41598-020-59394-5.

[55] Olmeda, B.; Martínez-Calle, M.; Pérez-Gil, J. Pulmonary Surfactant Metabolism in the Alveolar Airspace: Biogenesis, Extracellular Conversions, Recycling. Annals of Anatomy2017, 209, 78-92. https://doi.org/10.1016/j.aanat.2016.09.008.

[56] Bernhard, W.; Haslam, P. L.; Floros, J. From Birds to Humans: New Concepts on Airways Relative to Alveolar Surfactant. American Journal of Respiratory Cell and Molecular Biology. January 2004, pp 6-11. https://doi.org/10.1165/rcmb.2003-0158TR.

[57] Bernhard, W. Lung Surfactant: Function and Composition in the Context of Development and Respiratory Physiology. Annals of Anatomy. Elsevier GmbH November 1, 2016, pp 146-150. https://doi.org/10.1016/j.aanat.2016.08.003.

[58] Boyer, J. L. Bile Formation and Secretion. Comprehensive Physiology2013, 3 (3), 1035-1078. https://doi.org/10.1002/cphy.c120027.

[59] Secretion of Bile and the Role of Bile Acids In Digestion http://www.vivo.colostate.edu/hbooks/pathphys/digestion/liver/bile.html (accessed May 21, 2020). 
Role of Gemini Surfactants in Fight Against Covid19

[60] Buchweitz, M.; Kroon, P. A.; Rich, G. T.; Wilde, P. J. Quercetin Solubilisation in Bile Salts: A Comparison with Sodium Dodecyl Sulphate. Food Chemistry2016, 211, 356-364. https://doi.org/10.1016/j.foodchem.2016.05.034.

[61] Natural Organics Removal Using Membranes: Principles, Performance, and Cost - Andrea Schafer - Google Books

https://books.google.co.in/books?id=nUzMBQAAQBAJ\&pg=PA23\&lpg=PA23\&dq=nature+uses+concept+of +micelles+naturally\&source=bl\&ots=Dc_BmXRAb0\&sig=ACfU3U1PRJE3A0jA5-

suIsRG98RU7MfPgQ\&hl=en\&sa=X\&ved=2ahUKEwim6MqY7cPpAhUwxTgGHdn1Bd0Q6AEwEHoECAkQAQ\# $\mathrm{v}=$ onepage $\& \mathrm{q}=$ nature $\% 20$ uses $\% 20$ concept $\% 20$ of\%20micelles\%20naturally\&f=false (accessed May 21, 2020).

[62] Nakama, Y. Surfactants. In Cosmetic Science and Technology: Theoretical Principles and Applications; Elsevier Inc., 2017; pp 231-244. https://doi.org/10.1016/B978-0-12-802005-0.00015-X.

[63] Berg, J. C. Chapter V The Role of Surfactants. In Textile Science and Technology; Elsevier, 2002; Vol. 13, pp 149-198. https://doi.org/10.1016/S0920-4083(02)80008-1.

[64] Chapter 8 Application of Surface Activity in Therapeutics. In Studies in Interface Science; Elsevier, 2005 ; Vol. 21, pp 233-293. https://doi.org/10.1016/S1383-7303(05)80047-X.

[65] Wang, H.; Guo, W.; Zheng, C.; Wang, D.; Zhan, H. Effect of Temperature on Foaming Ability and Foam Stability of Typical Surfactants Used for Foaming Agent. Journal of Surfactants and Detergents2017, 20 (3), 615-622. https://doi.org/10.1007/s11743-017-1953-9.

[66] Fink, J. K. Surfactants. In Hydraulic Fracturing Chemicals and Fluids Technology; Elsevier, 2013; pp 121-127. https://doi.org/10.1016/B978-0-12-411491-3.00010-8.

[67] Jafarinejad, S. Oil-Spill Response. In Petroleum Waste Treatment and Pollution Control; Elsevier, 2017; pp 117-148. https://doi.org/10.1016/B978-0-12-809243-9.00004-3.

[68] Free, M. L. The Use of Surfactants to Enhance Particle Removal from Surfaces. In Developments in Surface Contamination and Cleaning: Second Edition; Elsevier Inc., 2016; Vol. 1, pp 595-626. https://doi.org/10.1016/B978-0-323-29960-2.00013-7.

[69] Kato, K. Tribological Implication of Particles. In Developments in Surface Contamination and Cleaning: Second Edition; Elsevier Inc., 2016; Vol. 1, pp 147-172. https://doi.org/10.1016/B978-0-323-29960-2.00005-8.

[70] Cole, D. A.; Attavar, S.; Zhang, L. Surface Analysis Methods for Contaminant Identification. In Developments in Surface Contamination and Cleaning: Second Edition; Elsevier Inc., 2016; Vol. 1, pp 333-394. https://doi.org/10.1016/B978-0-323-29960-2.00008-3.

[71] Kohli, R. Microabrasive Technology for Precision Cleaning and Processing. In Developments in Surface Contamination and Cleaning: Second Edition; Elsevier Inc., 2016; Vol. 1, pp 627-666. https://doi.org/10.1016/B978-0-323-29960-2.00014-9.

[72] Free, M. L. The Use of Surfactants to Enhance Particle Removal from Surfaces. In Developments in Surface Contamination and Cleaning: Second Edition; Elsevier Inc., 2016; Vol. 1, pp 595-626. https://doi.org/10.1016/B978-0-323-29960-2.00013-7.

[73] Randall, K.; Cheng, S. W.; Kotchevar, A. T. Evaluation of Surfactants as Solubilizing Agents in Microsomal Metabolism Reactions with Lipophilic Substrates. In Vitro Cellular and Developmental Biology - Animal2011, 47 (9), 631-639. https://doi.org/10.1007/s11626-011-9449-9.

[74] Brycki, B. E.; Kowalczyk, I. H.; Szulc, A.; Kaczerewska, O.; Pakiet, M. Multifunctional Gemini Surfactants: Structure, Synthesis, Properties and Applications. In Application and Characterization of Surfactants; InTech, 2017. https://doi.org/10.5772/intechopen.68755.

[75] Seredyuk, V.; Alami, E.; Nydén, M.; Holmberg, K.; Peresypkin, A. v.; Menger, F. M. Adsorption of Zwitterionic Gemini Surfactants at the Air-Water and Solid-Water Interfaces. Colloids and Surfaces A: Physicochemical and Engineering Aspects2002, 203 (1-3), 245-258. https://doi.org/10.1016/S0927-7757(01)01106-2.

[76] Sharma, R.; Kamal, A.; Abdinejad, M.; Mahajan, R. K.; Kraatz, H. B. Advances in the Synthesis, Molecular Architectures and Potential Applications of Gemini Surfactants. Advances in Colloid and Interface Science. Elsevier B.V. October 1, 2017, pp 35-68. https://doi.org/10.1016/j.cis.2017.07.032.

[77] Xu, Q.; Wang, L.; Xing, F. Synthesis and Properties of Dissymmetric Gemini Surfactants. Journal of Surfactants and Detergents2011, 14 (1), 85-90. https://doi.org/10.1007/s11743-010-1207-6.

[78] Smith, G. A. Fatty Acid, Methyl Ester, and Vegetable Oil Ethoxylates. In Biobased Surfactants; Elsevier, 2019; pp 287-301. https://doi.org/10.1016/b978-0-12-812705-6.00008-3. 
Rajpreet Kaur, and Dr. Anita Gupta

[79] Gerba, C. P. Quaternary Ammonium Biocides: Efficacy in Application. Applied and Environmental Microbiology. American Society for Microbiology 2015, pp 464-469. https://doi.org/10.1128/AEM.0263314.

[80] Tuladhar, E.; de Koning, M. C.; Fundeanu, I.; Beumer, R.; Duizer, E. Different Virucidal Activities of Hyperbranched Quaternary Ammonium Coatings on Poliovirus and Influenza Virus. Applied and Environmental Microbiology. American Society for Microbiology April 1, 2012, pp 2456-2458. https://doi.org/10.1128/AEM.07738-11.

[81] Shirai, J.; Kanno, T.; Tsuchiya, Y.; Mitsubayashi, S.; Seki, R. Effects of Chlorine, Iodine, and Quaternary Ammonium Compound Disinfectants on Several Exotic Disease Viruses. Journal of Veterinary Medical Science2000, 62 (1), 85-92. https://doi.org/10.1292/jvms.62.85.

[82] Tsao, I. -F; Wang, H. Y.; Shipman, C. Interaction of Infectious Viral Particles with a Quaternary Ammonium Chlorid (QAC) Surface. Biotechnology and Bioengineering1989, 34 (5), 639-646. https://doi.org/10.1002/bit.260340508.

[83] Weber, D. J.; Barbee, S. L.; Sobsey, M. D.; Rutala, W. A. The Effect of Blood on the Antiviral Activity of Sodium Hypochlorite, a Phenolic, and a Quaternary Ammonium Compound. Infection Control \& Hospital Epidemiology1999, 20 (12), 821-827. https://doi.org/10.1086/501591.

[84] Koziróg, A.; Kregiel, D.; Brycki, B. Action of Monomeric/Gemini Surfactants on Free Cells and Biofilm of AsaiaLannensis. Molecules2017, 22 (11). https://doi.org/10.3390/molecules22112036.

[85] Kamal, M. S. A Review of Gemini Surfactants: Potential Application in Enhanced Oil Recovery. Journal of Surfactants and Detergents. Springer Verlag March 1, 2016, pp 223-236. https://doi.org/10.1007/s11743015-1776-5.

[86] Kamal, M. S.; Sultan, A. S.; Hussein, I. A. Screening of Amphoteric and Anionic Surfactants for CEOR Applications Using a Novel Approach. Colloids and Surfaces A: Physicochemical and Engineering Aspects2015, 476, 17-23. https://doi.org/10.1016/j.colsurfa.2015.03.023.

[87] Zana, R. Dimeric and Oligomeric Surfactants. Behavior at Interfaces and in Aqueous Solution: A Review. Advances in Colloid and Interface Science. Elsevier March 29, 2002, pp 205-253. https://doi.org/10.1016/S0001-8686(01)00069-0.

[88] Zana, R. Dimeric (Gemini) Surfactants: Effect of the Spacer Group on the Association Behavior in Aqueous Solution. Journal of Colloid and Interface Science. Elsevier 2002, pp 203-220. https://doi.org/10.1006/jcis.2001.8104.

[89] Sikirić, M.; Šmit, I.; Tušek-Božić, L.; Tomašić, V.; Pucić, I.; Primožič, I.; Filipović-Vinceković, N. Effect of the Spacer Length on the Solid Phase Transitions of Dissymmetric Gemini Surfactants. Langmuir2003, 19 (24), 10044-10053. https://doi.org/10.1021/la034799e.

[90] Sikirić, M.; Primožič, I.; Filipović-Vinceković, N. Adsorption and Association in Aqueous Solutions of Dissymmetric Gemini Surfactant. Journal of Colloid and Interface Science2002, 250 (1), 221-229. https://doi.org/10.1006/jcis.2002.8304.

[91] Han, Y.; Wang, Y. Aggregation Behavior of Gemini Surfactants and Their Interaction with Macromolecules in Aqueous Solution. Physical Chemistry Chemical Physics2011, 13 (6), 1939-1956. https://doi.org/10.1039/c0cp01196g.

[92] Kaur, R.; Singh, K.; Khullar, P.; Gupta, A.; Ahluwalia, G. K.; Bakshi, M. S. Applications of Molecular Structural Aspects of Gemini Surfactants in Reducing Nanoparticle-Nanoparticle Interactions. Langmuir2019. https://doi.org/10.1021/acs.langmuir.9b02855.

[93] Mohajeri, E.; Dehghan, G. Effect of Temperature on the Critical Micelle Concentration and Micellization Thermodynamic of Nonionic Surfactants: PolyoxyethyleneSorbitan Fatty Acid Esters; Vol. 2012.

[94] McPherson, A. Micelle Formation and Crystallization as Paradigms for Virus Assembly. BioEssays2005, 27 (4), 447-458. https://doi.org/10.1002/bies.20196.

[95] Li, P. X.; Li, Z. X.; Shen, H. H.; Thomas, R. K.; Penfold, J.; Lu, J. R. Application of the Gibbs Equation to the Adsorption of Nonionic Surfactants and Polymers at the Air-Water Interface: Comparison with Surface Excesses Determined Directly Using Neutron Reflectivity. Langmuir2013, 29 (30), 9324-9334. https://doi.org/10.1021/la4018344.

[96] Bordes, R.; Holmberg, K. Amino Acid-Based Surfactants - Do They Deserve More Attention? Advances in Colloid and Interface Science. Elsevier August 12, 2015, pp 79-91. https://doi.org/10.1016/j.cis.2014.10.013. 
[97] Hayes, D. G.; Smith, G. A. Biobased Surfactants: Overview and Industrial State of the Art. In Biobased Surfactants; Elsevier, 2019; pp 3-38. https://doi.org/10.1016/b978-0-12-812705-6.00001-0.

[98] Somasundaran, P.; Fu, E.; McCue, K.; Boesenberg, D. Handbook for Cleaning/Decontamination of Surfaces i Chemical Disinfection of Hard Surfaces-Household, Industrial and Institutional Settings.

[99] Clark, P. G.; Wagener, T. J. Removal of Particles by Chemical Cleaning. In Developments in Surface Contamination and Cleaning: Second Edition; Elsevier Inc., 2008; Vol. 1, pp 579-593. https://doi.org/10.1016/B978-0-323-29960-2.00012-5.

[100] Use of Disinfectants: Alcohol and Bleach. 2014.

[101] RJ, R. A Plausible Penny Costing Effective Treatment for Corona Virus - Ozone Therapy. Journal of Infectious Diseases and Epidemiology.

[102] Dubuis, M. E.; Dumont-Leblond, N.; Laliberté, C.; Veillette, M.; Turgeon, N.; Jean, J.; Duchaine, C. Ozone Efficacy for the Control of Airborne Viruses: Bacteriophage and Norovirus Models. PLoS ONE2020, 15 (4). https://doi.org/10.1371/journal.pone.0231164.

[103] Elvis, A. M.; Ekta, J. S. Ozone Therapy: A Clinical Review. Journal of Natural Science, Biology and Medicine. January 2011, pp 66-70. https://doi.org/10.4103/0976-9668.82319.

[104] Ozone Can Be Used To Destroy The New Coronavirus And Disinfect Areas - Thailand Medical News https://www.thailandmedical.news/news/ozone-can-be-used-to-destroy-the-new-coronavirus-anddisinfect-areas (accessed May 31, 2020).

[105] Karaca, H.; Velioglu, Y. S. Ozone Applications in Fruit and Vegetable Processing. Food Reviews International2007, 23 (1), 91-106. https://doi.org/10.1080/87559120600998221.

[106] Nath, A.; Mukhim, K.; Swer, T.; Dutta, D.; Verma, N.; Deka, B. C.; Gangwar, B. A Review on Application of Ozone in the Food Processing and Packaging; 2014; Vol. 1. 